\begin{tabular}{|c|c|}
\hline Citation & $\begin{array}{l}\text { Jeroen Maesschalck (2020) } \\
\text { De toekomst is aan de surfende criminoloog } \\
\text { Tijdschrift voor criminologie } 61 \text { (4), 370-385. }\end{array}$ \\
\hline Archived version & $\begin{array}{l}\text { Author manuscript: the content is identical to the content of the published } \\
\text { paper, but without the final typesetting by the publisher }\end{array}$ \\
\hline Author affiliation & $\begin{array}{l}\text { Jeroen Maesschalck, Leuven Institute of Criminology, Faculty of Law, KU } \\
\text { Leuven (University of Leuven), Belgium }\end{array}$ \\
\hline Author contact & $\frac{\text { Jeroen.Maesschalck@kuleuven.be }}{+32(0) 16325588}$ \\
\hline
\end{tabular}




\section{De toekomst is aan de surfende criminoloog}

Jeroen Maesschalck, KU Leuven

\section{Table of Contents}

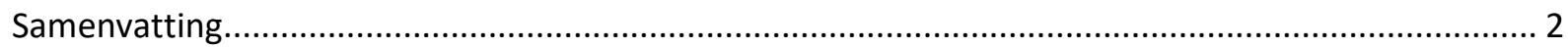

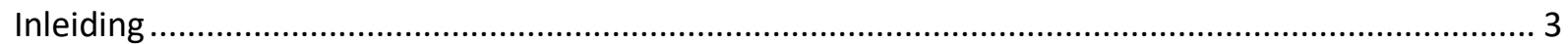

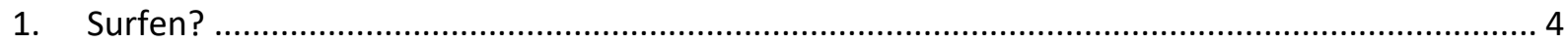

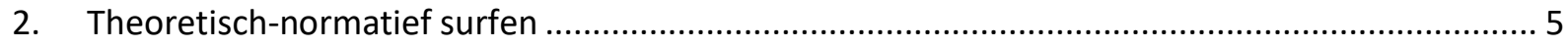

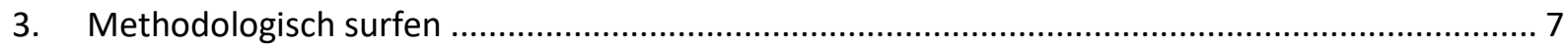

4. Criminologisch surfen in de praktijk: krijtlijnen voor een concrete onderzoeksagenda................. 8

5. Hoe kunnen we de financiering van dat criminologisch surfen organiseren? ............................. 10

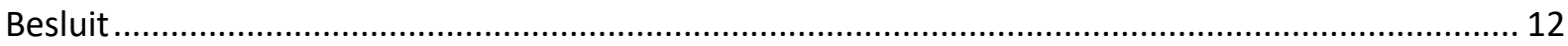

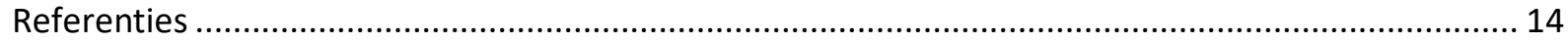

\section{Samenvatting}

Om een zinvolle bijdrage te leveren aan de aanpak van de grote uitdagingen die op ons afkomen moeten we als criminologen meer... surfen. In een dynamische omgeving vol tegenstellingen is het belangrijk dat we voortdurend over en weer bewegen, daarbij laverend tussen theoretischnormatieve benaderingen en tussen methodologische benaderingen. Na enkele illustraties om die surfende beweging concreet te maken, worden drie krijtlijnen voorgesteld voor een criminologische onderzoeksagenda die ons op weg kan helpen naar de aanpak van die grote uitdagingen: echte (i.p.v. oppervlakkige) praktijkrelevantie, causale ambities en multidisciplinariteit. De bijdrage rondt af met enkele reflecties over de organisatie en financiering van criminologisch onderzoek. 


\section{Inleiding}

Op een recent symposium ter gelegenheid van 90 jaar criminologie in Leuven gaf John Braithwaite een lezing over de publieke rol van de criminologie. De aula zal vol enthousiaste studenten en onderzoekers die helemaal klaar waren voor het optimistische verhaal over herstelrecht, 'responsive regulation' of andere innovaties dat we ondertussen van onze Australische collega gewoon zijn. Niemand was voorbereid op de koude douche die eraan kwam. Het werd een dramatisch verhaal over de gevolgen van drie dreigende rampen: klimaatverandering, een oorlog met massavernietigingswapens (hij maakte zich vooral zorgen over killer robots) en een economische crisis. De aanpak van dat soort bedreigingen, daar moet de criminologie zich op richten, zo stelde Braithwaite. Hij gaf meteen ook voorbeelden van hoe de criminologie dat zou kunnen doen, o.m. door meer onderzoek naar organisatiecriminaliteit. Zoals dat gaat bij koude douches stonden velen nadien nog wat na te trillen, maar hing er ook energie en ambitie in de lucht: misschien kunnen we toch iets doen aan die vele dreigingen die we vaak wat negeren maar die ons niettemin boven het hoofd hangen? De koude douche blijft in elk geval doorwerken tot ik nu, enkele weken later, dit stuk mag schrijven over de toekomst van criminologisch onderzoek. Inderdaad, criminologie moet minstens de ambitie hebben om iets te betekenen in het voorkomen of aanpakken van de grote uitdagingen die ons te wachten staan. Met een sussende, relativerende academische houding dat al dat gepraat over 'disruptie' overtrokken is zullen we er niet geraken.

Braithwaites lijstje van dreigingen was natuurlijk niet volledig. Hij had het niet over de dreigende generatieconflicten door vergrijzing, de uitdagingen ten gevolge van (klimaat)migratie, de groeiende ongelijkheid, de enorme druk op privacy door digitalisering, of de verruwing van het publieke debat en het succes van populisme. Het is trouwens ook niet alleen kommer en kwel in deze tijden van disruptie. 
Migratie, digitalisering en globalisering: ze bieden ook heel wat kansen, ook net om de eerder genoemde crisissen te helpen voorkomen of aanpakken. Het lijstje van uitdagingen is in elk geval veel langer dan de hier opgesomde voorbeelden. Bovendien kan voor elk van die uitdagingen apart een uitgebreid stuk worden geschreven over hoe criminologie kan helpen om er een antwoord op te formuleren. Dat is niet wat ik in deze bijdrage zal doen. Ik wil wel enkele reflecties formuleren over hoe een criminologische onderzoeksagenda die relevant wil zijn voor die uitdagingen er zou kunnen uitzien.

Om die bespreking wat concreter te maken, zal bij wijze van illustratie hier en daar wel verwezen worden naar één belangrijke uitdaging waar Braithwaite het niet over had: het groeiend belang van big data en artificiële intelligentie. De enorme toename in de hoeveelheid van beschikbare informatie en in de technische capaciteit om die te verwerken biedt spectaculaire mogelijkheden. Zo zullen we, via complexe algoritmes toegepast op grote datasets, steeds beter criminaliteit kunnen voorspellen. Dit kan de politie toelaten om via 'predictive policing' (Egbert \& Krasmann, 2019; Ferguson, 2017; Kaufmann, Egbert, \& Leese, 2019) in te grijpen nog voor feiten gepleegd zijn. Niet alleen de publieke politie is geïnteresseerd in big data, natuurlijk. In handen van grote bedrijven wordt al die kennis omgezet tot koopwaar in een wereld die gedomineerd dreigt te worden door "surveillance capitalism" (Zuboff, 2019). Bedrijven kunnen niet alleen analyseren wat u liket of doorstuurt op sociale media. Ze kunnen ook steeds meer uw emoties monitoren en dus tot koopwaar maken, bijvoorbeeld door analyse van biometrische informatie op smart watches, door herkenning van stempatronen via smart home producten als Alexa of door het monitoren van gezichtsuitdrukkingen in de publieke ruimte (Clifford, 2019). Met die kennis kunnen bedrijven mensen nog veel doelgerichter verleiden om hun producten te kopen of, bijvoorbeeld, om voor een bepaalde partij te stemmen. Maar natuurlijk ook criminele netwerken kunnen die expertise gebruiken, bijvoorbeeld om kwetsbare jongeren te manipuleren tot crimineel gedrag. Dus niet enkel onze privacy, maar ook onze autonomie in een nog veel fundamentelere betekenis worden hier bedreigd. Sommigen pleiten dan ook voor de introductie van een juridisch beschermd recht op "cognitive sovereignity" (Yeung, 2018). Criminologen hebben zeker al aandacht besteed aan deze ontwikkelingen en dreigingen. Er bestaan al heel wat kritische analyses van predictive policing (Ferguson, 2017; Kaufmann et al., 2019) of machine justice (Peeters \& Schuilenburg, 2018). Interessant zijn ook de studies van technieken van 'countersurveillance' waarbij politieambtenaren of rechters zelf, o.m. via sociale media, door burgers gemonitord worden en ter verantwoording worden geroepen (Stratton, Powell, \& Cameron, 2017, p. 26). Toch, zo zal in deze bijdrage geargumenteerd worden, maken criminologische onderzoekers het zichzelf soms onnodig moeilijk in dit soort onderzoek en zijn er ook nog veel onbenutte mogelijkheden.

Dat brengt ons terug bij de kernvraag: wat moeten criminologen doen om een zinvolle bijdrage te kunnen leveren aan de aanpak van de grote uitdagingen van de komende decennia? Het korte antwoord is: ze moeten meer surfen. In de eerste paragraaf wordt die surfmetafoor kort toegelicht. Vervolgens wordt toegelicht wat dat surfen concreet kan betekenen: er wordt gepleit voor surfen tussen theoretisch-normatieve benaderingen en vervolgens voor surfen tussen methodologische benaderingen. Nadien worden die ideeën concreter gemaakt in de vorm van drie krijtlijnen voor een criminologische onderzoeksagenda voor de toekomst. Tot slot wordt gereflecteerd over hoe de financiering van het criminologisch onderzoek best georganiseerd zou worden als we die onderzoeksagenda willen realiseren.

\section{Surfen? ${ }^{1}$}

Waarom zou een surfende houding de criminoloog helpen om beter te anticiperen en te reageren op de grote uitdagingen die ons wachten? De surfmetafoor kan heel wat inspiratie bieden, maar om niet

\footnotetext{
${ }^{1}$ Ik dank Rients Ritskes, die mij als eerste de rijkdom toonde van deze surfmetafoor.
} 
te verdrinken in de vele mogelijkheden ervan zal ik in deze bijdrage focussen op drie aspecten van surfen die een inspiratie kunnen vormen voor criminologisch onderzoek.

Ten eerste is het zo dat surfers worden geconfronteerd met een complexe, voortdurend veranderende omgeving. De golven en de wind dienen zich voor hen aan als een dynamisch 'veld' van vele, vaak contradictorische krachten. Ze kunnen en moeten daarin wel hun eigen weg kiezen, maar daarbij moeten ze wel rekening houden met de dynamiek van die vele krachten. Ten tweede zien we dat surfers in die complexe omgeving er soms voor kiezen om voluit naar één richting over te hellen. Als de golven dat vereisen kan dat inderdaad een heel goed idee zijn. Echter, ten derde, als die overhellende houding niet aangepast is aan de golven op dat moment of als de surfer die houding blijft volhouden terwijl de golven veranderen, dan zal die het evenwicht uiteindelijk verliezen en kopje onder gaan. Immers, om zich staande te houden in die dynamische omgeving vol tegenstellingen, moet de surfer een complexe en subtiele reeks van bewegingen maken die soms meegaan met de golven en er soms tegen ingaan. Het gaat dus om een continue evenwichtsoefening waarbij de surfer probeert recht te blijven door, aangepast aan de golven, steeds in beweging te blijven. Soms leidt dat tot prachtige elegante bewegingen, soms tot onhandig gestuntel, soms tot rampzalige mislukkingen. In de rest van dit stuk wil ik aantonen dat criminologisch onderzoek beter en relevanter zal worden als het zich laat inspireren door deze drie aspecten van surfen.

\section{Theoretisch-normatief surfen}

De drie genoemde aspecten van surfen kunnen inspirerend zijn voor de manier waarop criminologen zich verhouden tegenover de vele theoretische en normatieve perspectieven in hun domein. Ten eerste is het inderdaad zo dat criminologen geconfronteerd worden met een complex en dynamisch domein van diverse en vaak contradictorische theoretische en normatieve perspectieven waarin ze hun plaats moeten zoeken. Veiligheid en vrijheid zijn bijvoorbeeld twee essentiële doelstellingen in een democratische samenleving, maar ze zijn niet tegelijkertijd permanent te maximaliseren. In de penologie zal er altijd een debat blijven over het relatief belang van diverse strafdoelen die allemaal op zich legitiem zijn maar nooit allemaal tegelijk gemaximaliseerd kunnen worden. Van de politie verwachten we dat die niet enkel criminaliteit probeert te voorkomen en bestrijden, maar dat ook op een rechtvaardige manier doet. Ook die twee legitieme doelstellingen zijn vaak niet tegelijk te realiseren, al was het maar door tijdsgebrek (Bowling, 2007, p. 22). De lijst van spanningen tussen fundamentele waarden (en dus ook de theoretische perspectieven die eruit zijn afgeleid) die nooit helemaal verzoenbaar zijn is dus vrijwel eindeloos en criminologen moeten een eigen weg zien te vinden tussen al die contradictorische perspectieven.

Ten tweede zie je dat ook criminologen soms voluit voor één perspectief gaan. Dan wordt bijvoorbeeld in een technocratisch discours enkel gekeken naar de effectiviteit van politie en wordt procedurele rechtvaardigheid over het hoofd gezien. Anderen benadrukken dan weer uitdrukkelijk procedurele rechtvaardigheid als het enige dat er echt toe doet. Echter, ten derde, als we als criminologen te lang eenzijdig voor één perspectief gaan, dan dreigen serieuze problemen. Als we enkel de nadruk leggen op effectiviteit, dan vergeten we dat procedurele rechtvaardigheid soms ook de effectiviteit kan versterken, bijvoorbeeld doordat burgers makkelijker zullen meewerken met een politie die ze vertrouwen. Een te eenzijdige nadruk op effectiviteit kan, paradoxaal genoeg, dus die effectiviteit ondermijnen. Hetzelfde zien we aan de andere kant van het spectrum. Voorstanders van procedurele rechtvaardigheid lijken soms zo enthousiast dat ze vergeten dat een te eenzijdige nadruk op die procedurele rechtvaardigheid uiteindelijk ook de effectiviteit van het politiewerk kan ondermijnen. Met name als de effectiviteit van de politie (vb. inzake criminaliteitsbestrijding) erg diep gezakt is, is het wellicht beter om vooral daar iets aan te doen en pas in tweede orde aan procedurele rechtvaardigheid te werken (Bradford, Huq, Jackson, \& Roberts, 2014). Ook in het domein van 
predictive policing kunnen we de risico's zien van het te eenzijdig benadrukken van één perspectief. Veel criminologen wijzen terecht op de vele risico's van dit soort gebruik van big data. Zo kan het ongelijkheden die al bestaan nog versterken vermits criminaliteit uit het verleden als predictor wordt gebruikt voor criminaliteit in de toekomst. Vertekeningen uit het verleden kunnen dus in een feedbacklus versterkt worden in de toekomst (Ferguson, 2017). Die eenzijdig-kritische analyse volstaat echter niet. Ze is het criminologische equivalent van een surfer die steeds naar dezelfde kant overhelt en dus uiteindelijk zal omslaan. Veel interessanter zijn analyses waar de verschillende waarden tegelijkertijd serieus worden genomen, ook die waar predictive policing wel een gunstige impact op kan hebben, zoals veiligheid. Criminologische reflectie wordt dan veel meer een subtiel spel van creatief over en weer bewegen tussen verschillende visies. In zo een spel kan men ervoor kiezen om voluit prioriteit geven aan één waarde, maar dan wel in het besef dat de andere waarden ook belangrijk blijven en dat continu overhellen naar één kant leidt tot problemen. In veel gevallen zal trouwens blijken dat het niet om louter tegengestelde waarden gaat, maar dat ze elkaar soms wederzijds kunnen versterken: veiligheid is tot op zekere hoogte een voorwaarde voor vrijheid en omgekeerd. Als predictive policing vooral wordt ingezet ter preventie van die misdrijven waar burgers in sociaal achtergestelde buurten het meest last van hebben, dan kan het gelijkheid juist versterken. Voor dit soort creatieve oplossingen is een surfende houding veel nuttiger dan een rigide keuze voor één perspectief.

In dit licht wordt het in de toekomst nog belangrijker dan nu dat criminologen bewust reflecteren over de risico's van al die innovaties, niet alleen die waar ze al kritisch over zijn, maar ook die waar ze enthousiast over zijn. Gemeenschapsgerichte politiezorg, een favoriet van veel politieonderzoekers, kan het risico op corruptie en collusie vergroten. Procedurele rechtvaardigheid bij de politie heeft veel mooie effecten, maar dat vriendelijk en correct optreden kan ook een manier zijn om meer fundamentele ongelijkheden te camoufleren. MacCoun (2005) gebruikt hiervoor het marxistisch begrip 'vals bewustzijn': procedurele rechtvaardigheid wordt dan gezien als een instrument van manipulatie, een manier om kritiek op ongelijkheden te vermijden. Dit waren slechts twee voorbeelden. Er zijn risico's te bedenken bij zowat alle interventies in ons domein. Van artsen verwachten we dat, als ze medicijnen voorschrijven, ze ook rekening houden met de bijwerkingen. Dat is niet alleen hun technisch-medische, maar ook hun morele verantwoordelijkheid. In ons enthousiasme voor een bepaalde benadering dreigen wij als criminologen dat wel eens te vergeten. Dat geldt trouwens niet alleen voor de beleidsinterventies die we voorstellen, maar ook voor ons eigen onderzoek. Onze inzichten in gedragsbeïnvloeding kunnen ten goede gebruikt worden in criminaliteitspreventie, maar kunnen ook misbruikt worden voor commerciële doeleinden of voor sinistere vormen van overheidssurveillantie. Nog veel meer dan vroeger zullen we ons dus bewust moeten zijn van die risico's. Gelukkig betekent dat niet dat criminologen gedoemd zijn om mompelende criticasters te worden die bij alle innovatieve voorstellen enkel wijzen op de risico's en nadelen. Het betekent evenmin dat criminologen zich moet laten verlammen door angst voor de vele manieren waarop hun onderzoek misbruikt zou kunnen worden. Dat zou het equivalent zijn van een surfer die zo verkrampt is dat hij bij de eerste grote golf onderuit gaat door zich angstig te verzetten in plaats van er door een dynamische evenwichtsoefening gebruik van te maken. Natuurlijk mogen criminologen enthousiast zijn over innovaties, al dan niet zelf bedacht. Maar dat ontslaat hen niet van de verantwoordelijkheid om meteen ook zelf al na te denken over de risico's en de ongewenste effecten ervan. Nu vinden we die reflecties nog te veel in aparte kampen: de enthousiastelingen tegenover de critici. Van onderzoekers mogen we verwachten wat we ook van artsen verwachten: een gezonde balans tussen enthousiasme over de mogelijkheden en bewustzijn van de risico's. In deze tegelijk fascinerend en beangstigende tijd zou dat een kernambitie van criminologisch onderzoek moeten zijn. Zoals de 'bijsluiter' bij medicijnen zouden ook criminologische studies en beleidsvoorstellen een paragraaf moeten bevatten met mogelijke neveneffecten en de condities waaronder die zich kunnen voordoen.

De complexe evenwichtsoefening tussen tegengestelde normatieve perspectieven verwachten we trouwens niet enkel van criminologische onderzoekers, maar ook van actoren in de praktijk. Ook 
street-cops, cipiers, privédetectives, preventiewerkers of beleidsadviseurs moeten voortdurend dynamisch balanceren tussen tegenstrijdige waarden. In sommige gevallen zal dat heel erg overhellen naar één waarde, maar dan wel in het volle besef dat ook de andere waarden belangrijk blijven. Hier zit overigens een heel interessante opportuniteit voor verder onderzoek. Er is merkwaardig weinig echte theorievorming over deze complexe evenwichtsoefening door praktijkcriminologen. Men gebruikt wel metaforen als surfen, tapdansen (Hendriks \& Van Hulst, 2016) of 'bricolage' (Levi-Strauss, 1966). Die zijn interessant, maar hun analytische kracht voor het beschrijven en verklaren van gedrag blijft toch beperkt. Criminologisch onderzoek hiernaar zou inspiratie kunnen halen bij enkele fascinerende theoretische ontwikkelingen in zusterdisciplines. In de beleidswetenschappen, bijvoorbeeld, ontwikkelt men typologieën over de verschillende manieren waarop beleidsmakers en uitvoerders kunnen omgaan met tegengestelde waarden (Stewart, 2006; Thacher \& Rein, 2004). In de managementwetenschappen is er een groeiende literatuur over paradoxen en de verschillende strategieën die managers kunnen hanteren om daar in een dynamische evenwichtsoefening mee om te gaan (Smith \& Lewis, 2011; Smith, Lewis, Jarzabkowski, \& Langley, 2017). Voor criminologen is theorievorming over die evenwichtsoefening een grotendeels onontgonnen maar veelbelovend terrein.

\section{Methodologisch surfen}

Ook de reflectie over methodologische benaderingen in criminologisch onderzoek kan geïnspireerd worden door de surfmetafoor. Ten eerste worden criminologen ook op methodologisch vlak geconfronteerd met een complex veld van tegengestelde perspectieven. Zo is er de succesvolle experimentele criminologie met haar sterk geloof in één type onderzoeksdesign en een groot vertrouwen dat op basis van cumulatief onderzoek duidelijke richtlijnen gegenereerd kunnen worden voor 'evidence-based' beleid. Aan de andere van het spectrum vinden we benaderingen als de kritische criminologie of de culturele criminologie die o.m. machtsdynamieken en uitsluitingsmechanismen willen blootleggen. Ten tweede zien we ook op methodologisch vlak heel wat criminologische onderzoekers die, in termen van onze surfmetafoor, voluit naar één richting overhellen en dus dreigen kopje onder te gaan. Ze geraken in een soort van radicaliseringsproces: ze sluiten zich op in een echokamer met gelijkgezinden en kiezen ervoor om andersgezinde onderzoekers te negeren of te demoniseren. Voor de 'randomistas', bijvoorbeeld, is de randomized controlled trial de goudstandaard voor wetenschappelijk onderzoek (Leigh, 2018). Al het andere onderzoek wordt grotendeels genegeerd; het is immers toch niet wetenschappelijk. Ze vergeten daarbij natuurlijk dat ze door al hun inspanningen om de werkelijkheid in een kwantitatief, experimenteel design te persen, een groot deel van die werkelijkheid missen en bovendien veel impliciete normatieve keuzes maken. De kritische criminologen aan de andere kant van spectrum zijn veel minder goed in negeren. Zij zullen juist het debat opzoeken met de 'conventionele criminologie' en haar neiging om bestaande machtsstructuren en uitsluitingsmechanismen te legitimeren. In hun tunnel vergeten die kritische criminologen dan weer vaak wel dat ze op die manier zelf aan uitsluiting doen van wie een andere mening heeft.

Dat brengt ons bij de derde parallel met surfen. Veel zinvoller dan die zelfradicalisering in gezellige echokamers is een strategie waarbij criminologen, als handige surfers, in een dynamische balanceeroefening laveren tussen de extremen. Afhankelijk van het thema en de precieze onderzoeksvraag kiezen ze soms voor het ene extreem, soms voor het andere, maar vaak ook voor een tussenpositie of een combinatie. Volgens sommigen betekent dit dat die balanceeroefening vooral een heel rationele, koele, technische oefening moet worden. Eén voorbeeld hiervan is het antwoord van Hough (2011) op het enthousiasme bij veel Britse beleidsmakers over experimenteel onderzoek. Hij stelt voor om evaluatieve onderzoeksvragen te situeren op een continuüm van complexiteit. Aan de ene kant van het continuüm bevinden zich de vragen die zo simpel zijn dat er geen experimenten nodig zijn om ze te beantwoorden en aan de andere kant de vragen die te complex zijn voor experimenteel 
onderzoek. Enkel onderzoek in het midden van dat continuüm is geschikt voor experimenteel onderzoek. Dit voorstel van Hough is een voorbeeld van hoe een methodologisch debat 'afgekoeld' kan worden tot een louter technisch vraagstuk: welk type onderzoeksvraag hangt samen met welke onderzoeksstrategie? Dit doet wat denken aan een standpunt dat Loader en Sparks (2011) geregeld zien terugkomen in inhoudelijke criminologische debatten en waar ze weinig enthousiast over zijn. Veel criminologen, zo stellen ze vast, streven ernaar om de oververhitte publieke toon van penal populism te helpen afkoelen door criminologie te reduceren tot een meer bezadigde reflectie over technocratische vragen en antwoorden. Ook in de methodologie is dat een verleidelijke optie: laat ons die ouderwetse, ideologisch gekleurde, vurige methodenstrijd vervangen door een veel rustiger, technisch gesprek over de juiste methoden bij de juiste onderzoeksvraag. Dat is ook ongeveer het verhaal dat ik lang aan studenten heb verteld in de lessen onderzoeksmethodologie: vroeger had je hitsige, passionele ruzies tussen academici over methodologie (dat beeld leidt dan vaak tot wat gegniffel bij studenten), maar dat zijn we nu ontgroeid. Nu gaat het, zo zei ik dan, veel meer om een technische zoektocht naar het juiste design voor de te beantwoorden onderzoeksvraag. De jongste jaren vind ik dat ik dat verhaal echter opnieuw wat moet nuanceren: eigenlijk is die afkoeling er nooit echt geweest en bovendien is die eigenlijk ook niet wenselijk. Achter de methodologische en inhoudelijke keuzes die men maakt tijdens een onderzoek schuilen natuurlijk ook ethische en ideologische keuzes en het is veel beter om die te expliciteren dan om te doen alsof ze er niet zijn. Dat er dus verschillende visies zijn op wat goed criminologisch onderzoek is en dat de debatten over die visies passioneel kunnen worden is niet het probleem, integendeel. Het wordt wel een probleem als er niet meer geluisterd wordt doordat de 'aanhangers' van de verschillende visies elkaar negeren of demoniseren. Dat de verschillende methodologische scholen steeds meer eigen tijdschriften en eigen academische netwerken ontwikkelen is vanuit dit perspectief eigenlijk geen goed nieuws. Wel hoopgevend in dit verband is het blijvend succes van brede fora als de European Society of Criminology waar echte debatten tussen de verschillende visies mogelijk blijven. Aan onderzoekers die werken aan hun literatuurstudie wordt wel eens geadviseerd om in de bibliotheek niet alleen het boek te nemen dat ze via de catalogus gevonden hadden, maar ook het boek ernaast mee te nemen. Dat kan serendipiteit uitlokken en creativiteit bevorderen. Misschien moeten we dat advies ook ter harte nemen bij de volgende criminologische conferentie en eens binnengaan in de sessie naast de sessie die we in het programma hadden aangeduid?

\section{Criminologisch surfen in de praktijk: krijtlijnen voor een concrete onderzoeksagenda}

In de voorgaande paragrafen werd gepleit voor criminologie als een dynamische evenwichtsoefening tussen waarden, theorieën en methodologische benaderingen. In deze paragraaf wordt dat uitgewerkt in drie concrete krijtlijnen voor een criminologische onderzoeksagenda voor de toekomst: criminologisch onderzoek moet nog meer praktijkrelevant worden, het moet ambitieuzer worden in het formuleren van causale claims en het moet nog meer multidisciplinair en interdisciplinair worden.

Voor de eerste krijtlijn keren we terug naar de oorspronkelijke ambitie van deze bijdrage: criminologie moet nog veel meer dan nu de ambitie hebben om een bijdrage te leveren aan de aanpak van de grote uitdagingen. We hebben dus meer nood aan echt praktijkrelevant onderzoek. Dat betekent uiteraard niet dat het louter om beleidsgerichte onderzoeksprojecten moet gaan. Ook proefschriften of grote fundamentele onderzoeksprojecten kunnen praktijkrelevant zijn. Dat betekent evenmin dat dit onderzoek niet theoriegestuurd zou mogen zijn. Integendeel, zo zegt Garland (2011, p. 302), juist omdat criminologisch onderzoek te weinig theoriegestuurd was, heeft het in het verleden vaak te laat gereageerd op maatschappelijke ontwikkelingen. In een themagestuurde onderzoeksagenda zal men immers minder snel nieuwe thema's oppikken dan in een theoriegestuurde agenda waarin nieuwe 
ontwikkelingen gezien kunnen worden als voorbeelden van een meer algemeen fenomeen (Garland, 2011, p. 302).

Hoe ziet die praktijkrelevante agenda er dan wel uit? We kunnen die natuurlijk verengen tot de 'what works?' benadering: interventies worden geëvalueerd in strakke (quasi-)experimentele designs en de inzichten eruit worden samengebracht in meta-analyses die de basis vormen voor 'evidence-based beleid'. Maar veel interessanter is het om die agenda te verbreden. Ook diepgaand etnografisch onderzoek naar de impact van een nieuwe politiestrategie of kritisch-criminologische analyses van predictive policing praktijken kunnen hieronder passen, zolang er maar lessen uit te trekken zijn voor de praktijk. Een bijzondere vorm van praktijkgericht onderzoek is dat onderzoek waar de onderzoekers zelf mee interventies ontwerpen. Ook hier lijkt het vaak alsof men tussen extremen moet kiezen. Ofwel vindt de onderzoeker het vooral belangrijk dat de mensen op wie de interventie gericht is mee de interventie mogen vormgeven en dan zal die voor een vorm van participatief actie-onderzoek gaan. Ofwel veronderstelt de onderzoeker dat mensen rationele actoren zijn met dezelfde voorkeuren en dan kiest hij of zij voor benaderingen zoals de situationele criminaliteitspreventie. Maar ook hier is de onderzoeker niet gedoemd in één van die perspectieven te blijven steken en is dynamisch surfen tussen beide extremen aangewezen. Criminologie kan hier trouwens nuttige inspiratie halen uit de design science benadering in het managementonderzoek (van Aken, 2004; van Aken \& Romme, 2012) die o.m. de technische aspecten van design combineert met participatieve strategieën.

Voor de tweede krijtlijn bouwen we verder op het hoger geformuleerde pleidooi voor methodologisch surfen. Als criminologisch onderzoek echt zinvol advies wil geven over de grote uitdagingen die ons wachten, dan zal het ook veel ambitieuzer moeten zijn in het formuleren van causale claims. Bij causaliteit wordt vaak meteen gedacht aan (quasi-)experimentele designs. Die zijn uiteraard relevant, maar de jongste decennia is er veel meer gebeurd op dit terrein. Een onderzoeker kan nu kiezen uit een heel breed aanbod van kwantitatieve, kwalitatieve en mixed methods benaderingen die allemaal op hun eigen manier causale uitspraken beogen (Mahoney \& Goertz, 2006). In diverse handleidingen zie we hoe bijvoorbeeld ook op basis van gevalstudies (Bennett \& Checkel, 2015; George \& Bennett, 2005) of met de hulp van qualitative comparative analysis (Rihoux \& Ragin, 2009) valide causale uitspraken mogelijk zijn. Helaas worden die nieuwe methodologische inzichten, op enkele uitzonderingen na, nog maar weinig gebruikt in criminologisch onderzoek. Eén uitzondering daarop is de, weliswaar nog bescheiden, criminologische onderzoekslijn die gebruikt maakt van 'realist evaluation' (Farrell \& Sidebottom, 2019; Pawson, 2013; Pawson \& Tilley, 1997). Dat is een evaluatiemethodologie die toelaat om causale mechanismen bloot te leggen die bijvoorbeeld kunnen verklaren waarom een interventie al dan niet tot de beoogde gedragsverandering leidt. Maar veel criminologisch onderzoek lijkt causaliteit dus vooral te willen vermijden. Men heeft het dan over 'risicofactoren', 'correlaten' of 'patronen', maar zeker niet over oorzaken of causale mechanismen. Ironisch genoeg wordt daarmee impliciet het idee bevestigd dat het experimentele design de goudstandaard is voor causale uitspraken. Zo laat men het terrein van de causaliteit helemaal aan de experimentele criminologen. In de praktijk blijkt trouwens vaak dat in die 'niet-causale' onderzoeken, ondanks alle voorzichtigheid, uiteindelijk wel causale claims worden geformuleerd. Dat gebeurt dan en passant en dus zonder een bewuste reflectie over, bijvoorbeeld, alternatieve verklaringen, de mate waarin echt naar falsificatie is gezocht, de mate waarin een effect afhankelijk is van contextfactoren, enz. Het is veel beter om wel expliciet causale uitspraken te beogen, maar daarbij dan wel heel bewust te reflecteren over hun validiteit.

De aanstormende tsunami (om in de watermetaforen te blijven) van big data analyses maakt de behoefte aan goed doordachte en empirisch uitgeteste causale theorieën trouwens nog dringender. Eén van de belangrijkste claims van de big data beweging is immers dat causale theorieën relieken uit het verleden zullen worden (Chan \& Bennett Moses, 2016; Mayer-Schönberger \& Cukier, 2013). Door de enorme hoeveelheid data zal het mogelijk worden om louter op basis van correlaties gedrag te voorspellen, zonder dat men nog een verklaring nodig heeft voor die correlaties. Bovendien zullen die 
correlaties gevonden worden door datawetenschappers uit de techbedrijven, niet door sociale wetenschappers uit universiteiten of overheidsinstellingen (Chan \& Bennett Moses, 2016). Die datawetenschappers kunnen dus op termijn aan beleidsmakers, politieambtenaren en andere praktijkmensen gedragsvoorspelling en zelfs gedragsbeïnvloeding aanbieden en dat allemaal zonder de academische moeilijkdoenerij van criminologen. Dat wordt een verleidelijk voorstel voor die praktijkmensen en het is aan ons als criminologen om in die context aan te tonen dat ons onderzoek wel nog een meerwaarde heeft. Onze morele, kritische reflecties over de gevaren van al dat voorspel en gemanipuleer zullen zinvol blijven, maar ze zullen niet volstaan. We zullen moeten kunnen aantonen dat ons onderzoek wél echt kan helpen om interventies te verbeteren. Wat wij immers kunnen bieden is inzicht in hoe een interventie werkt. Dat inzicht verwerf je niet door de loutere observatie van correlaties (zelfs in gigantische datasets), maar door diepgaand onderzoek, met behulp van het breed pallet aan beschikbare methodologieën, naar de werkzame causale mechanismen.

Dat we in de toekomst nog meer multidisciplinair en interdisciplinair zullen moeten samenwerken, de derde krijtlijn voor een criminologische onderzoeksagenda, is wellicht de grootste open deur van deze bijdrage, maar dat maakt de stelling niet minder waar. Ook hier gaat het om een permanente evenwichtsoefening waarbij de surfende criminoloog zijn of haar middelpunt weliswaar in de criminologie heeft, maar tegelijkertijd ook over en weer beweegt tussen andere disciplines en daarbij soms ook stevig overhelt. Garland zegt het met een wat andere, maar ook waterachtige metafoor: criminologie "needs to remain [...] grounded in multiple disciplines, not floating independent of them" (Garland, 2011, p. 314). Een mooi voorbeeld van dit surfen is de recente analyse van Peeters en Schuilenburg (2018) over 'machine justice'. Hun vaststelling dat het gebruik van algoritmes in politie en justitie leidt tot een versterking van de bureaucratie en de vervanging van 'street-level bureaucrats' door 'screen-level bureaucrats' is natuurlijk sterk geïnspireerd door de bestuurskunde, maar blijft niettemin in de kern van de criminologie. Dat dit soort inter- en multidisciplinaire samenwerking nog moet versterkt worden stellen ook Stratton et al. (2017) vast op basis van hun analyse van onderzoek naar criminaliteit en justitie in de digitale samenleving. Een grote uitdaging daarbij wordt samenwerking met datawetenschappers en computerwetenschappers (Smith, Bennett Moses, \& Chan, 2017, p. 269). In de vorige alinea werden ze nog voorgesteld als concurrenten, maar uiteraard zijn het vooral ook partners. Alleen met hun hulp kunnen we proberen begrijpen hoe de algoritmes achter, bijvoorbeeld, predictive policing werken. Gemakkelijk wordt die taak niet gezien de grote complexiteit van veel van die machine learning algoritmes (Chan \& Bennett Moses, 2016, pp. 30-31). Misschien kunnen we hier ons voordeel doen met een aangepaste versie van het advies dat wij destijds als studenten kregen over ingewikkelde mathematische modellen in de rationele keuzeliteratuur: zelfs als je er maar een klein beetje van begrijpt, lees toch door en laat je vooral niet intimideren door de technische taal; als het niet juist voelt, neem dat gevoel dan zeker ernstig.

\section{Hoe kunnen we de financiering van dat criminologisch surfen organiseren?}

Wie een onderzoeksagenda voorstelt denkt natuurlijk ook best een stap verder: wie zal dat betalen en hoe worden die middelen best verdeeld? Over de financiering van criminologisch onderzoek is veel te zeggen: de onderzoeksbudgetten van heel wat ministeries en andere organisaties uit onze sector slinken, het is niet gemakkelijk om met een kritische blik te kijken naar de hand waaruit men eet, enz. Op deze thema's is elders al grondig ingegaan. In dit stuk wil ik mij beperken tot twee reflecties.

De eerste overweging heeft te maken met de organisatie van beleidsgericht onderzoek. Ook hier bevinden criminologische onderzoekers zich in een complex veld van contrasterende visies en belangen. Bij beleidsgericht onderzoek moeten ze laveren tussen de korte en de lange termijn, tussen onafhankelijkheid en betrokkenheid, tussen wetenschappelijke grondigheid en bruikbaarheid, tussen 
wetenschappelijke criteria en beleidscriteria, enz. Hoe kunnen opdrachtgevers hun financiering zo organiseren dat criminologen gestimuleerd en geholpen worden om op een slimme, correcte manier te surfen tussen al die belangen en visies? Nogal wat beleidsmakers, zeker in België, lijken te denken dat dit het best gebeurt via individuele, vaak kortlopende onderzoeksprojecten die nauw worden opgevolgd door de opdrachtgever zodat die de praktijkrelevantie heel goed in de gaten kan houden. Een dergelijk model kan inderdaad nuttig zijn voor sommige specifieke types van onderzoek, zoals een kosten-baten analyse van een concrete beleidsinterventie of de valorisatie van eerder onderzoek door het uitwerken van een concrete tool. Voor veel andere types van onderzoek lijkt dit financieringsmodel veel minder geschikt. Het kan snel leiden tot oppervlakkige en weinig kritische resultaten waar ook de opdrachtgever weinig aan heeft (tenzij louter als legitimering van het beleid). Voor echt grondig en bruikbaar beleidsgericht onderzoek lijkt het veel wenselijker dat opdrachtgevers een omgeving creëren waarin onderzoekers op lange termijn kunnen laveren tussen al die verschillende waarden en belangen. Eén beproefde manier voor opdrachtgevers om dat te doen is door te investeren in langdurige samenwerkingsverbanden tussen diverse onderzoeksinstellingen die ook nauw samenwerken met mensen uit de praktijk. Die financiering kan dan binnen het consortium verdeeld worden en gespreid worden over lange onderzoeksprojecten (bv. doctoraten), kortere onderzoeksprojecten én valorisatieopdrachten. Een dergelijk langdurig, structureel samenwerkingsverband creëert een relatief veilige 'branding' aan de kust waarbinnen al surfend geëxperimenteerd kan worden: onderzoekers kunnen risico's nemen in het besef dat als ze eens kopje onder gaan dit de samenwerking niet onmiddellijk in het gevaar zal brengen. Een dergelijk financieringsmodel lijkt in elk geval vruchtbaarder dan een model waarin onderzoekers tegen elkaar worden uitgespeeld in een competitie voor kortdurende, praktijkgerichte onderzoeksprojecten. De zogenaamde 'steunpunten beleidsrelevant onderzoek' in Vlaanderen zijn een uitstekend voorbeeld van die langdurige samenwerkingsverbanden. Dat zij de jongste jaren werden gedecentraliseerd op Vlaams niveau en dat er nooit echt een dergelijke financiering heeft bestaan op federaal niveau toont dat er, zeker in België, nog ruimte is om de financiering van beleidsgericht onderzoek te verbeteren.

De tweede overweging handelt niet over de financiering van het beleidsgerichte, maar van het zogenaamde fundamenteel onderzoek: langdurige projecten met wetenschappelijke finaliteit, typisch uitgevoerd door doctorandi en postdocs. Het is met name nuttig en belangrijk om te kijken naar de criteria die gebruikt worden om dit onderzoek te financieren. Ik beperk me hier tot een kritische blik op twee criteria die jongste tijd zo belangrijk worden dat ze surfende criminologen soms zwaar doen overhellen: innovatie en (sociale) impact.

Ten eerste blijken fondsen en instellingen die middelen voor fundamenteel onderzoek mogen verdelen veel belang te hechten aan het innovatief karakter van onderzoeksprojecten. Daar is natuurlijk veel voor te zeggen. Als criminologie inderdaad de ambitie heeft om de grote uitdagingen van de toekomst te helpen aanpakken, dan is innovatief onderzoek naar nieuwe thema's onvermijdelijk. Maar dat verantwoordt niet de obsessie met innovatie die we nu soms zien. In de praktijk leidt die niet zelden gewoon tot herverpakking: wil je financiering, dan is het een goed idee om de recente buzzwords te gebruiken en jouw onderzoek te verpakken als iets nieuws dat nog nooit gedaan is, liefst als een 'paradigmashift' of iets 'disruptief'. Die permanente herverpakking in steeds maar nieuwe labels en modellen is niet alleen onnodig tijdverlies; ze belemmert ook de cumulatieve opbouw van echt diepgaande kennis. Ze dreigt ons te verblinden voor terugkerende diepere patronen in het gedrag van mensen en instituties die we al lang kennen en waarover al veel theorie bestaat. Veel perverse effecten van zogenaamd nieuwe beleidsparadigma's had men wellicht kunnen voorzien als men had begrepen dat het nieuwe paradigma eigenlijk verwijst naar bekende patronen die al uitgebreid bestudeerd zijn. Een bijkomend probleem is dat die druk om alles als nieuw en innovatief te verpakken er paradoxaal genoeg toe leidt dat de échte paradigmashifts dreigen te verdrinken in die zee van trendy labels. Als politieonderzoekers zijn we ondertussen zo afgestompt door de eindeloze stroom van naar paradigmashiften verwijzende adjectieven (zero tolerance, problem-oriented, community-oriented, multiple community-oriented, intelligence-led, reassurance, plural, nodal, restorative, abstract ... 
policing ), dat we het misschien niet meer zullen merken wanneer er een echte disruptie zou plaatsvinden in de politiepraktijk. Financiers van fundamenteel onderzoek zouden die nieuwigheidsobsessie dus eigenlijk moeten afremmen in plaats van versterken. Ze zouden dan meteen ook meer aandacht kunnen besteden aan belangrijk onderzoek dat nu ondergefinancierd wordt omdat het niet als innovatief kan verpakt worden. Het gaat dan bijvoorbeeld om replicatie-onderzoek, om longitudinaal onderzoek waarbij dezelfde survey jaarlijks herhaald wordt, of om cumulatieve studies waarin een bestaande (en niet noodzakelijk modieuze) theorie geleidelijk aan verder wordt verfijnd.

Een tweede criterium waar financiers van fundamenteel onderzoek soms in dreigen door te slaan is (sociale) impact. Ook dit is in principe natuurlijk belangrijk, zeker voor een onderzoeksagenda die praktijkrelevant wil zijn. Natuurlijk is het goed dat ook onderzoekers op tijd en stond ter verantwoording worden geroepen over de impact van hun werk in de samenleving. Maar ook hier wordt het gevaarlijk als financiers zo overhellen dat ze het tegenovergestelde bereiken van wat ze beogen. De aandacht voor sociale impact gaat dan ten koste van aandacht voor andere criteria, zoals methodologische kwaliteit. Het risico bestaat dat onderzoeksmethodologie dan wordt weggezet als technische, academische spielerei met weinig sociale impact. Onderzoek waarin bijvoorbeeld verschillende meetmethoden met elkaar worden vergeleken of waarin diep wordt nagedacht over de validiteit van causale uitspraken, maakt dan veel minder kans op financiering dan methodologisch oppervlakkige studies die wel een grote sociale impact beloven. Het is niet moeilijk om te zien hoe dat contraproductief kan werken. Methodologisch zwak onderzoek kan leiden tot foute conclusies en slechte aanbevelingen die niet alleen grote maatschappelijke schade kunnen aanrichten, maar ook het vertrouwen in de wetenschap kunnen verzwakken. Het is trouwens een misverstand dat diepgaande aandacht voor onderzoeksmethoden onverenigbaar zou zijn met grote sociale impact. Nadat politieonderzoekers methodologisch hadden geëxperimenteerd met participerende observatie bleek dat hun inzichten over o.m. politiecultuur veel meer sociale impact hadden dan de zogenaamde praktijkgerichte studies uit die tijd. Als onderzoekers volgens de methodologie van 'realist evaluation' samen met praktijkmensen reflecteren over de causale mechanismen die verondersteld worden achter een beleidsinterventie, dan heeft ook die methodologische sérieux een gunstige impact op de praktijk.

Dat overheden, liefdadigheidsfondsen of bedrijven die beleidsgericht onderzoek financieren soms te wat te ver doorslaan in hun focus op innovatie en sociale impact is jammer, maar ook wel te begrijpen. Ook zij staan immers vaak onder grote druk om 'de boot niet te missen' en 'om een verschil te maken'. Het is veel moeilijker te verantwoorden dat ook de fondsen die middelen voor fundamenteel onderzoek mogen verdelen vallen voor die obsessie met innovatie en impact. Vanuit hun rol zouden zij immers juist een vrijhaven moeten bieden: een plaats waar onderzoekers niet gedwongen worden om nieuwe modellen, benaderingen en labels te 'marketen' als innovatief en vol impact ("Nieuwe formule! Met nog betere werking!"). Er zijn genoeg anderen die die markt van trendy modellen en benaderingen kunnen innemen en financieren. Het belastingsgeld dat is vrijgemaakt voor fundamenteel onderzoek zou daarentegen gebruikt moeten worden voor onderzoek dat er wel toe doet, maar door die markt niet of te weinig wordt gefinancierd. Het gaat dan bijvoorbeeld om methodologisch stevig onderbouwd onderzoek naar actuele maar niet noodzakelijk trendy thema's dat gebruik maakt van, soms reeds lang bestaande, theoretische inzichten om op zoek te gaan naar recurrente patronen en net daardoor ook disrupties kan zien en duiden. Kortom, als de samenleving dreigt te kapseizen in de richting van een obsessie met nieuwigheid en onmiddellijke nuttigheid, dan moet fundamenteel onderzoek niet meebewegen, maar juist naar de andere richting duwen.

\section{Besluit}

Criminologisch onderzoek moet veel meer dan nu de ambitie hebben om een bijdrage te leveren aan de aanpak van de grote uitdagingen van onze tijd. Dat was de stelling waar deze bijdrage van vertrok. 
Daarbij werd ook vastgesteld dat criminologen het op dit moment zichzelf soms onnodig moeilijk maken door zich op te sluiten in één visie en, in de surfmetafoor, dus vervaarlijk over te hellen in één richting. Veel meer kans op succes hebben slim surfende criminologen die zich bewust zijn van de vele contradicties waartussen zij zich bewegen en via een dynamische balanceeroefening creatief op zoek gaan naar hun eigen weg tussen die tegenstellingen. Predictive policing, bijvoorbeeld, is zeker niet ondubbelzinnig goed omdat het criminaliteit kan voorspelen of helpen voorkomen, maar het is evenmin ondubbelzinnig slecht omdat het gelijke behandeling en autonomie bedreigt. Predictive policing is een complexe verzameling van mogelijke praktijken in een ingewikkeld veld van waarden (vb. vrijheid, gelijkheid, veiligheid) die elkaar tegelijk tegenspreken en versterken. Ook inzake onderzoeksmethodologie kunnen we nog veel meer surfen. Door slim heen en weer te bewegingen tussen methodologische benaderingen, zullen we meer gehoord worden en ook een veel rijker, genuanceerder en praktijkrelevanter verhaal kunnen vertellen.

Deze bijdrage suggereerde ook drie krijtlijnen voor een onderzoeksagenda voor de toekomst. Criminologisch onderzoek zal nog meer praktijkrelevant moeten worden dan nu. Het moet 'evidence' willen bieden voor evidence-based beleid, maar dan wel met een onderzoeksagenda die veel breder gaat dan (quasi-)experimentele designs. Daarnaast moet criminologisch onderzoek nog veel meer dan nu de ambitie hebben om echt causale verklaringen te bieden, bijvoorbeeld door op zoek te gaan naar de causale mechanismen die verklaren waarom een interventie al dan niet werkt. Daarbij maken ze best gebruik van het volledige pallet aan methodologieën om causaliteit vast te stellen. Causaliteit is immers veel te belangrijk om over te laten aan de experimentele criminologen. Tot slot moeten criminologen ook surfen in een inter- en multidisciplinaire context: vlot heen en weer bewegen tussen de zuster- en moederdisciplines van criminologie maar zonder hun criminologische middelpunt en dus hun evenwicht te verliezen. Een van de grootste, maar ook meest fascinerende uitdagingen daarbij wordt wellicht de samenwerking met de datawetenschappers in de techbedrijven.

Metaforen kunnen verhelderen, maar kunnen ook leiden tot misverstanden. Ter afronding van deze bijdrage wil ik nog kort ingaan op twee misverstanden die zouden kunnen rijzen uit de surfmetafoor. Ten eerste zou de vergelijking met een erg technische activiteit als surfen de indruk kunnen werken dat dit stuk pleit voor een soort 'technocratisering' van de criminologie, weg van de grote ethische en ideologische debatten. Het hogere pleidooi voor praktijkrelevant 'evidence-based beleid' zou dat misverstand nog kunnen versterken. Dat zou dan wel echt een misverstand zijn. De oproep om uit de theoretisch-normatieve echokamers te komen heeft niet als bedoeling om ideologie minder belangrijk te maken, maar integendeel om juist tot een echt gesprek te komen tussen de contrasterende visies. In die zin is dit stuk geen technocratisch maar juist een uitgesproken moreel pleidooi. Het is immers een uitdrukkelijk morele keuze om ervan uit te gaan dat tegengestelde visies elk zowel hun sterktes als hun risico's hebben, zodat men steeds moet surfen tussen die visies in een dynamische balanceeroefening. Ten tweede lijkt het geformuleerde pleidooi tegen de extreme echokamers en voor genuanceerde visies op het eerste zicht misschien op een pleidooi voor een permanente middenpositie of gulden middenweg. Dat is het zeker niet. De surfer die krampachtig recht wil blijven en weigert om gebruik te maken van de beweging van de golven zal ook kopje onder gaan. Deze bijdrage is dus zeker geen pleidooi tegen de experimentele of de kritische criminologie; het is een pleidooi tegen een naïef en blind geloof in die benaderingen (of in elke andere benadering). Natuurlijk kunnen onderzoekers beslissen dat de situatie vereist om voluit voor een extreme benadering te gaan. Zij doen dat dan echter wel best in het besef dat ze zullen moeten terugkeren of toch minstens dat er andere, gelijkwaardige benaderingen zijn waarmee ze de dialoog zullen moeten blijven aangaan. In die zin lijken criminologische onderzoekers van de toekomst meer op wijkagenten en straathoekwerkers die een complexe sociale dynamiek op een pleintje met veel overlast proberen te beheren, dan op de zuivere, rechtlijnige academici die het cliché soms wil. 


\section{Referenties}

Bennett, A., \& Checkel, J. T. (Eds.). (2015). Process tracing. From metaphor to analytical tool. Cambridge: Cambridge University Press.

Bowling, B. (2007). Fair and effective policing methods: towards 'good enough' policing. Journal of Scandinavian Studies in Criminology and Crime Prevention, 8(1), 17-32. doi:10.1080/14043850701695023

Bradford, B., Huq, A., Jackson, J., \& Roberts, B. (2014). What price fairness when security is at stake? Police legitimacy in South Africa. Regulation \& Governance, 8(2), 246-268. doi:10.1111/rego.12012

Chan, J., \& Bennett Moses, L. (2016). Is big data challenging criminology? Theoretical Criminology, 20(1), 21-39.

Clifford, D. (2019). The legal limits to the monetisation of online emotions. Doctoral dissertation. Leuven: KU Leuven.

Egbert, S., \& Krasmann, S. (2019). Predictive policing: not yet, but soon preemptive? Policing and Society, 1-15. doi:10.1080/10439463.2019.1611821

Farrell, G., \& Sidebottom, A. (2019). Realist evaluation for crime science: essays in honour of Nick Tilley. Oxon: Routledge.

Ferguson, A. G. (2017). Policing predictive policing. Washington University Law Review, 94(5), 11091189.

Garland, D. (2011). Criminology's place in the academic field. In M. Bosworth \& C. Hoyle (Eds.), What is criminology? (pp. 298-317). Oxford: Oxford University press.

George, A. L., \& Bennett, A. (2005). Case studies and theory development in the social sciences. Cambridge: MIT Press.

Hendriks, F., \& Van Hulst, M. (2016). Shifting repertoires: understanding cultural plurality in policing. Innovation: the European journal of social science research, 29(2), 161-176.

Hough, M. (2011). Criminology and the role of experimental research. In M. Bosworth \& C. Hoyle (Eds.), What is criminology? (pp. 198-208). Oxford: Oxford University Press.

Kaufmann, M., Egbert, S., \& Leese, M. (2019). Predictive policing and the politics of patterns. The British Journal of Criminology, 59, 674-692.

Leigh, A. (2018). Randomistas: how radical researchers changed our world. Carlton, Australia: La Trobe University Press.

Levi-Strauss, C. (1966). The savage mind. Chicago: University of Chicago Press.

Loader, I., \& Sparks, R. (2011). Criminology's public roles: a drama in six acts. In M. Bosworth \& C. Hoyle (Eds.), What is criminology? (pp. 17-34). Oxford: Oxford University Press.

MacCoun, R. J. (2005). Voice, control, and belonging: the double-edged sword of procedural fairness. Annual Review of Law and Social Science, 1(1), 171-201. doi:10.1146/annurev.lawsocsci.1.041604.115958

Mahoney, J., \& Goertz, G. (2006). A tale of two cultures: Contrasting quantitative and qualitative research. Political analysis, 14(3), 227-249.

Mayer-Schönberger, V., \& Cukier, K. (2013). Big data: A revolution that will transform how we live, work, and think. Boston: Houghton Mifflin Harcourt.

Pawson, R. (2013). The science of evaluation: a realist manifesto. London: Sage.

Pawson, R., \& Tilley, N. (1997). Realistic evaluation. London: Sage.

Peeters, R., \& Schuilenburg, M. (2018). Machine justice: governing security through the bureaucracy of algorithms. Information Polity, 23, 1-14.

Rihoux, B., \& Ragin, C. C. (Eds.). (2009). Configurational comparative methods: Qualitative comparative analysis (QCA) and related techniques (Vol. 51). Thousand Oaks: Sage Publications. 
Smith, G. J., Bennett Moses, L., \& Chan, J. (2017). The challenges of doing criminology in the big data era: towards a digital and data-driven approach. The British Journal of Criminology, 57(2), 259-274.

Smith, W. K., \& Lewis, M. W. (2011). Toward a theory of paradox: a dynamic equilibrium model of organizing. The Academy of Management Review, 36(2), 381-403. doi:10.5465/AMR.2011.59330958

Smith, W. K., Lewis, M. W., Jarzabkowski, P., \& Langley, A. (2017). The Oxford handbook of organizational paradox. Oxford: Oxford University Press.

Stewart, J. (2006). Value conflict and policy change. Review of Policy Research, 23(1), 183-195. doi:10.1111/j.1541-1338.2006.00192.x

Stratton, G., Powell, A., \& Cameron, R. (2017). Crime and justice in digital society: towards a 'digital criminology'? International Journal for Crime, Justice and Social Democracy, 6(2), 17-33.

Thacher, D., \& Rein, M. (2004). Managing value conflict in public policy. Governance, 17(4), 457-486. doi:10.1111/j.0952-1895.2004.00254.x

van Aken, J. E. (2004). Management research based on the paradigm of the design sciences: the quest for field-tested and grounded technological rules. Journal of Management Studies, 41(2), 219-246. doi:10.1111/j.1467-6486.2004.00430.x

van Aken, J. E., \& Romme, A. G. L. (2012). A design science approach to evidence-based management. In D. M. Rousseau (Ed.), The Oxford handbook of evidence-based management (pp. 43-57). Oxford: Oxford University Press.

Yeung, K. (2018). A study of the implications of advanced digital technologies (including Al systems) for the concept of responsibility within a human rights framework. Retrieved from

Zuboff, S. (2019). The age of surveillance capitalism. The fight for a human future at the new frontier of power. New York: Public Affairs, Hachette Book Group. 